\title{
Effects of temperature on heat-shock responses and survival of two species of marine invertebrates from sub-Antarctic Marion Island
}

\author{
S. CLUSELLA-TRULLAS ${ }^{\mathbf{1}}$, L. BOARDMAN ${ }^{\mathbf{2}}$, K.T. FAULKNER ${ }^{\mathbf{1}}$, L.S. PECK ${ }^{\mathbf{3}}$ and S.L. CHOWN ${ }^{\mathbf{4}}$ \\ ${ }^{I}$ Centre for Invasion Biology, Department of Botany and Zoology, Stellenbosch University, Private Bag XI, \\ Stellenbosch 7602, South Africa \\ ${ }^{2}$ Department of Conservation Ecology and Entomology, Stellenbosch University, Private Bag X1, Stellenbosch 7602, South Africa \\ ${ }^{3}$ British Antarctic Survey, NERC, High Cross, Madingley Road, Cambridge CB3 OET, UK \\ ${ }^{4}$ School of Biological Sciences, Monash University, VIC 3800, Australia \\ sct333@sun.ac.za
}

\begin{abstract}
This study examined high temperature survival and heat shock protein 70 (Hsp70) responses to temperature variation for two marine invertebrate species on sub-Antarctic Marion Island. The isopod Exosphaeroma gigas Leach and the amphipod Hyale hirtipalma Dana had the same tolerance to high temperature. The mean upper temperature which was lethal for $50 \%$ of the population (upper lethal temperature, $\mathrm{ULT}_{50}$ ) was $26.4^{\circ} \mathrm{C}$ for both species. However, the isopod E. gigas showed significant plasticity of $\mathrm{ULT}_{50}$, with a positive response to acclimation. In addition, the isopod had a heat shock response of Hsp70 at all acclimations, and the amount of $\mathrm{Hsp} 70$ protein increased significantly from basal levels upon an acute warm exposure after a cold acclimation. By contrast, the amphipod H. hirtipalma showed limited plasticity of $\mathrm{ULT}_{50}$ and no evidence for a heat shock response (failure of three different Hsp70 antibodies to bind to the extracted 70kDa proteins). Overall, these results reflect different flexibility of thermal tolerance of intertidal invertebrate species on Marion Island, with possible variation in the underlying cellular mechanisms, suggesting that warming associated with climate change may result in changes in species assemblage structure in sub-polar environments.
\end{abstract}

Received 21 February 2013, accepted 18 May 2013

Key words: Crustacea, heat stress, Hsp70, intertidal, microclimate, phenotypic plasticity

\section{Introduction}

Intertidal organisms often encounter extreme variation in temperature depending on their geographic location, season, timing of tides and their microsite position (aspect and degree of exposure). Despite polar terrestrial climates being generally more stable than those at mid-latitudes, polar intertidal environments can have substantial environmental variability, especially in the upper intertidal zone (Davenport \& Macalister 1996, Peck et al. 2006). In the sub-Antarctic, intertidal invertebrates may encounter significant temperature variation due to frequent wave splash and extreme events that increase the periods or frequency of immersion. For example, by its location coinciding with the 'Roaring Forties (latitudes)', Marion Island is subject to frequent frontal systems and migratory anticyclones. The island's coastal shores are frequently exposed to large swells and severe wave action, but also to periods with low wave height (De Villiers 1976, Rouault et al. 2005). Therefore, organisms in the intertidal zone have probably maintained or evolved physiological tolerance to varying abiotic stresses including temperature.

One of the ways organisms can cope with large thermal variation is via reversible phenotypic plasticity (within lifetime plasticity or thermal acclimation) which provides the organism with a compensatory physiological response when facing challenging conditions. In theory, individuals from constant thermal regimes should be less capable of modifying physiological function through acclimation than animals from environments that undergo more frequent and larger temperature variation within single generations (Gabriel \& Lynch 1992). However, most studies that compare the plasticity of temperature tolerance across latitudes or regions that differ in temperature variability do not support this pattern (see Angilletta 2009 for a review). In marine systems, eurythermal intertidal species often lack or have limited acclimatory ability despite the large temperature variation encountered in their habitats (Stillman \& Somero 2000). This limitation is probably due to the unpredictability of the intertidal environment (i.e. a lack of consistent cues for detecting temperature extremes), or the duration of the exposure if too short relative to the time course of acclimation effects (e.g. Sinclair et al. 2006) and/or to the fact that these species already live close to their upper temperature limit. As a consequence, an additional plastic response would result in increased costs (Stillman \& Somero 2000, Stillman 2003).

Heat shock proteins (Hsps) have been shown to play a significant role in the thermal tolerance of nearshore marine 

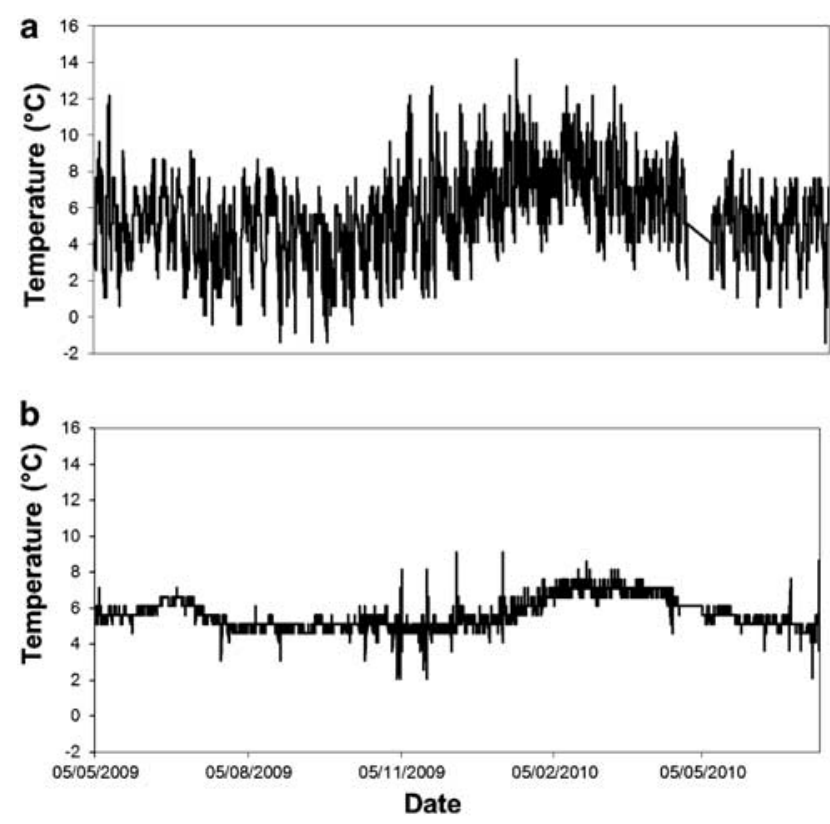

Fig. 1. Temperature profiles for a. semi-exposed, and b. submerged microsites of the intertidal rocky shore of Trypot Beach, Marion Island. Temperatures ranged from -1.4 to $14.2^{\circ} \mathrm{C}\left(\right.$ mean $\pm \mathrm{SD}$ of $5.6 \pm 2.3^{\circ} \mathrm{C}$ ) and 2.1 to $9.1^{\circ} \mathrm{C}$ $\left(5.7 \pm 0.8^{\circ} \mathrm{C}\right)$ for exposed and submerged sites, respectively.

invertebrates by stabilizing and refolding denatured proteins under stressful conditions (Tomanek \& Somero 1999, Tomanek 2010). Although a few studies indicate that stress proteins belonging to the family Hsp70 are up-regulated after heat exposures in marine invertebrates (e.g. Chapple et al. 1998, Tomanek \& Somero 1999, Buckley et al. 2001, Osovitz \& Hofmann 2005), data for sub-Antarctic species are limited. This is despite a recent effort to examine species in the Antarctic (e.g. La Terza et al. 2001, Clark et al. 2008a, 2008b) which generally have poor acclimation capacities (Peck et al. 2010). Several studies have demonstrated that the plasticity of the temperature at which Hsps are induced can be influenced by laboratory acclimation (Barua \& Heckathorn 2004), and thus, Hsp responses in intertidal organisms should be affected by the temperatures encountered in their natural habitat (Tomanek \& Somero 2002). Therefore, investigating the Hsp response of intertidal organisms as a result of different thermal histories, both acute and longer-term exposures, is essential for understanding how these organisms may cope with temperature variability. To our knowledge, no studies have investigated variation in heat shock protein 70 (Hsp70) response to acclimation or acute temperature change in sub-Antarctic marine invertebrates.

This study examines the magnitude of plasticity of upper thermal tolerance of two nearshore crustaceans from subAntarctic Marion Island, the isopod Exosphaeroma gigas Leach, and the amphipod Hyale hirtipalma Dana, and relates the results to the temperatures that the species experience under natural conditions. It also assesses the variation in the Hsp70 response, estimated using Western blotting of whole animal protein content, induced by acute temperature exposure and short-term acclimation. The results of this study provide information that is essential to assess which intertidal species have the ability to mount plastic physiological responses and whether Hsp70 is likely to play a mechanistic role in these responses, and may contribute to inform estimates of invertebrate population extinctions in the face of climate change in the region (Kelly et al. 2011).

\section{Methods \\ Species microsite use and temperatures}

The amphipod $H$. hirtipalma and isopod $E$. gigas inhabit the mid- to lower-littoral zones on Marion Island, which at the study site at Trypot Beach (46 $\left.53^{\prime} 09^{\prime \prime} \mathrm{S}, 37^{\circ} 52^{\prime} 37^{\prime \prime} \mathrm{E}\right)$ are characterized by small boulders mostly covered by decomposing kelp Durvillaea antarctica (Chamisso) Hariot. Hyale hirtipalma (body mass: $60.0 \pm 38.2 \mathrm{mg}$, $n=300$ ) is typically found among the boulders and algal fronds (semi-exposed sites; Fig. 1a), while E. gigas $(106.1 \pm 70.3 \mathrm{mg}, n=276)$ favours the substrate under boulders (submerged sites, Fig. 1b; De Villiers 1976, Branch et al. 1991), and therefore encounters more stable temperatures. I-button data loggers (DS1922L, $\pm 0.5^{\circ} \mathrm{C}$, Dallas Semiconductor Maxim, USA) protected in highly conductive capsules (DS1907, Dallas Semiconductor Maxim, USA) were deployed at semi-exposed and submerged positions of the shore at Trypot Beach to encompass microsites used by $H$. hirtipalma and E. gigas, respectively. Microsite temperature data were recorded at 90 min intervals from May 2009-September 2010 (Fig. 1).

\section{Acclimation treatments and upper lethal limits}

Several hundred individuals of each of the species were collected in April 2010 and maintained in temperatureregulated, oxygenated tanks at $6.7 \pm 0.2^{\circ} \mathrm{C}$ for $1-3$ days to allow habituation to new conditions. For each species, individuals were allocated haphazardly to three acclimation treatments: $3^{\circ} \mathrm{C}(2.8 \pm 0.3$, verified using I-button loggers, DS1922L $), 7^{\circ} \mathrm{C}(6.7 \pm 0.2)$ and $11^{\circ} \mathrm{C}(11.2 \pm 0.6)$ for $5-12$ days with a $12: 12 \mathrm{~h}$ light photoperiod. These temperature treatments reflect low, average and high seawater temperatures experienced at the collection site (Fig. 1). Filtered, fresh seawater and standardized amounts of food (D. antarctica kelp) were provided every three days. Water temperature was monitored using thermocouples (type T, gauge 24) and handheld thermometers (CHY 507, Taiwan) and recorded using I-button data loggers protected in silicone capsules (SL-ACC06, Signatrol, Tewkesbury, 
Table I. Results of Generalized Linear Models testing the effects of test temperature (TT) and acclimation temperature on the survival of two crustacean species from Marion Island.

\begin{tabular}{llcrc}
\hline Species & Effect & df & \multicolumn{1}{c}{$\chi^{2}$} & $P$ \\
\hline Hyale hirtipalma & TT & 5 & 241.84 & $<0.001$ \\
& Acclimation & 2 & 1.48 & 0.48 \\
Exosphaeroma gigas & TT & 8 & 239.03 & $<0.001$ \\
& Acclimation & 2 & 77.50 & $<0.001$ \\
\hline
\end{tabular}

UK). Salinity and dissolved oxygen levels in the tanks were monitored throughout the acclimation periods using appropriate meters (YSI 30 Salinity Conductivity and Temperature Meter, Ohio, USA; Lutron Dissolved Oxygen Meter DO-5510, Taipei, Taiwan). No mortalities were recorded during acclimations. To assess acclimation effects on the upper lethal temperature limits, a static $\mathrm{ULT}_{50}$ protocol was followed for each acclimation group using standard methods (Davenport \& Davenport 2005).

Five to ten individuals from each acclimation group were placed in a small container filled with filtered sea water, preheated to the required experimental temperature. Individuals were exposed for two hours to pre-determined test-temperatures (TT) maintained by water-circulating baths (Grant Instruments GP 200-R4, Cambridge, UK). A wide range of TT was employed, with treatments added based on the organism's responses to preliminary trials. Temperature trials were rotated across acclimation groups so that individuals were acclimated for a similar period across treatments. Seawater was aerated using air pumps during the exposures and, salinity, conductivity and dissolved oxygen monitored before and after each experiment. Individuals were then placed at $7^{\circ} \mathrm{C}$ where individual responses were checked after $10 \mathrm{~min}$ and 1 hour. The number of dead and live individuals was determined to score percentage mortality, and each individual's sex and body mass were determined using a microscope (Stemi 2000-C, Zeiss, New Jersey, USA) and balance (AE163 Mettler, Sartorius Analytic, Germany; $\pm 0.01 \mathrm{~g}$ ), respectively. Each test temperature was replicated at least three times.

For Hsp70 assessments, four individuals of each species were used in the following treatments: 1) field fresh (directly collected from the field), 2) acclimated at 3,7 or $11^{\circ} \mathrm{C}$, 3) acclimated at 3,7 or $11^{\circ} \mathrm{C}$ and then exposed to 2 hours at $25^{\circ} \mathrm{C}$ treatment, and 4) acclimated at 3,7 or $11^{\circ} \mathrm{C}$ and then exposed to 2 hours at $7^{\circ} \mathrm{C}$ treatment (representing controls for treatment (3)). After each treatment, individuals were snap frozen and kept at $-80^{\circ} \mathrm{C}$ until later Hsp70 assays took place at Stellenbosch University (South Africa).

\section{Protein extraction, quantification and sample preparation}

Prior to protein extraction, individuals were thawed from $-80^{\circ} \mathrm{C}$ and weighed (MS104S, Mettler Toledo, Switzerland).
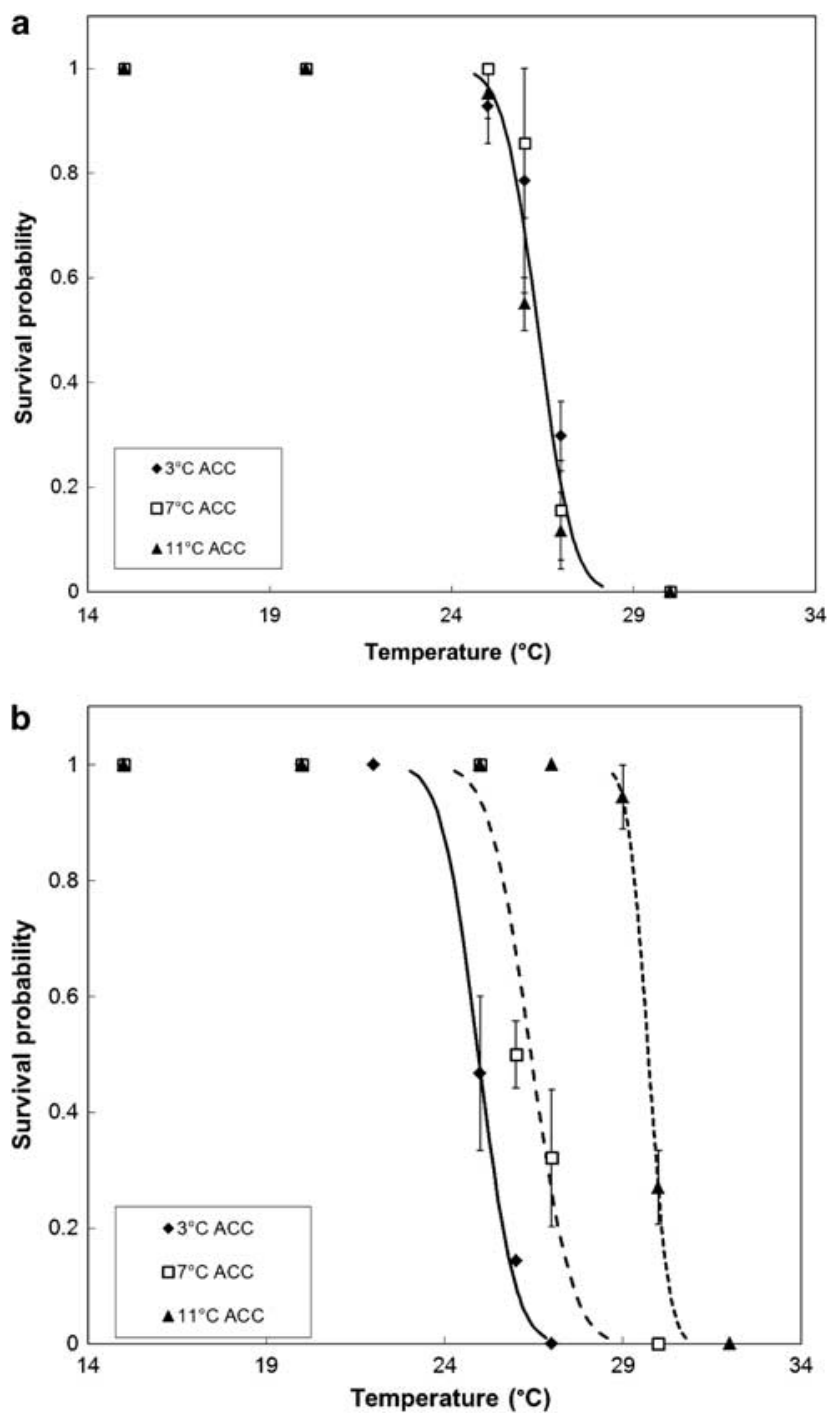

Fig. 2. Measured survivorship of a. the amphipod Hyale hirtipalma, and b. the isopod Exosphaeroma gigas as a function of temperature. Logit linear regressions are fitted for each 5-12 day acclimation: cold acclimation in solid line $\left(3^{\circ} \mathrm{C}\right)$, average seawater temperature in stippled line $\left(7^{\circ} \mathrm{C}\right)$ and warm acclimation in dotted line $\left(11^{\circ} \mathrm{C}\right)$. Means \pm s.e. are presented for each exposure.

Samples were kept on ice between steps in the weighing process. Protein samples were obtained by homogenizing whole individual samples in $400 \mu \mathrm{l}$ cold phosphate buffered saline (PBS) containing $2 \mathrm{mM}$ Pefabloc ${ }^{\circledR}$ (Sigma-Aldrich Pty. Ltd, Johannesburg, South Africa) and a $1 \%$ volume antiprotease cocktail $(100 \mathrm{ul} / \mathrm{ml}$ pepstatin A, $50 \mathrm{ul} / \mathrm{ml}$ leupeptin, $10 \mathrm{mM}$ benzamidine, $10 \mathrm{mM}$ sodium metabisulfite) (Karl et al. 2009). The homogenate was centrifuged at $4^{\circ} \mathrm{C}$ at $11000 \mathrm{~g}(13000 \mathrm{rpm})$ for $30 \mathrm{~min}$ and the supernatant transferred to a new microfuge tube. Protein supernatants were quantified using a BCA assay kit (Pierce) on a ND1000 spectrophotometer (Nanodrop Technologies). 
Samples of $50 \mu \mathrm{g}$ protein were prepared for sodiumdodecyl-sulphate polyacryamide gel electrophoresis (SDS-PAGE) by adding equal parts protein supernatant and SDS loading buffer $(100 \mathrm{mM}$ Tris, $4 \%$ SDS, $20 \% \mathrm{v} / \mathrm{v}$ glycerol, $0.2 \%$ bromophenol blue, $10 \% \mathrm{v} / \mathrm{v}$ $\beta$-mercaptoethanol). Prepared samples were denatured at $95^{\circ} \mathrm{C}$ for $5 \mathrm{~min}$ before being stored at $-80^{\circ} \mathrm{C}$ until further analysis with Western blotting.

\section{Western blot analysis}

Each precast gel $(7.5 \%$ resolving gel, $4 \%$ stacking gel, Ready Gel Tris-HCl, BioRad) was loaded with protein marker (SpectraTM Multicolor Broad Range Protein Ladder, Fermentas), positive control (HeLa cytoplasmic lysate, Abcam) and six samples. Gels were run in Tris-glycine running buffer $(25 \mathrm{mM}$ Tris, $192 \mathrm{mM}$ glycine, $1 \%$ SDS, $\mathrm{pH}$ c. 8.3 ) at $100 \mathrm{~V}$ for $75 \mathrm{~min}$ in a BioRad Mini Protean(R) Tetra Cell (PowerPac Basic). Proteins were transferred onto a PVDF membrane using the Invitrogen iBlot transfer system ( $20 \mathrm{~V}$ for $7 \mathrm{~min}$ ) and transfer stacks (Invitrogen). The membrane was incubated overnight using the Western Card system (Invitrogen) in an Invitrogen BenchPro ${ }^{\mathrm{TM}} 4100$ card processing station. The membrane was blocked for $60 \mathrm{~min}$ in 5\% non-fat instant milk powder solution made in Tris-buffered saline with Tween-20 (TBST; $20 \mathrm{mM}$ Tris, $\mathrm{pH} 7.5,150 \mathrm{mM} \mathrm{NaCl}$, $0.1 \%$ Tween-20), and incubated with primary antibody (monoclonal anti-heat shock protein 70 antibody produced in mouse, clone BRM-22, 1: 2500, Sigma \# H5147) in 5\% milk-TBST for $900 \mathrm{~min}$ and secondary antibody (HRPconjugated rabbit anti-mouse IgG, 1:10000, Abcam \# 6728) in 5\% milk-TBST for 60 min. Heat shock protein 70 polyclonal antibody (D69, Cell Signalling) and mouse monoclonal to Hsp70 (C92F3A, Abcam) were also trialled as primary antibodies, but did not yield positive results in either species. Washing steps with $5 \%$ milk-TBST were performed between each of the incubation steps. The primary antibody detects both the constitutive (Hsp73) and inducible (Hsp72) forms of Hsp70 (referred to as Hsp70 for simplicity). To detect the presence of Hsp70, the membrane was incubated in Super Signal West Chemiluminescent substrate (Pierce, Thermo Scientific) and exposed to film (Amersham Hyperfilm MP) for between $30 \mathrm{sec}$ and $10 \mathrm{~min}$. The film was developed in an automatic autoradiography film processor (Hyperprocessor, Amersham Pharmacia Biotech). Membranes were stained with Ponceau S solution (Sigma) to serve as an internal control of equal loading (Romero-Calvo et al. 2010). Films and membranes were analysed using an HP Scanjet 8200 scanner and Image J (version $1.44 p$, US National Institutes of Health, Bethesda, MD, http://imagej.nih.gov/ij) following Ferreira \& Rasband (2011). The density of each sample band at $70 \mathrm{kDa}$ was calculated relative to the density of the positive control (relative units, RU) for both the Ponceau-stained membrane and the film. The RUs for the film were adjusted to account for any differences in gel loading using the RUs from the membrane. The positive control served as the standard to allow for comparisons of relative densities between Western blots. At least three replicates of each sample were obtained for data analysis.

\section{Statistical analyses}

The upper lethal temperature tolerance of $50 \%$ of the sampled population $\left(\mathrm{ULT}_{50}\right)$ for each acclimation temperature was calculated using a non-linear model (proc-probit) in SAS version 9.2 (SAS Institute Inc, Cary, USA). Statistically homogenous groups were identified using overlap of $95 \%$ confidence intervals. The effect of acclimation temperature, test temperature and their interaction on survival (number of individuals alive/total number of individuals tested as the dependent variable) was determined using a Generalized Linear Model (GLZ) in

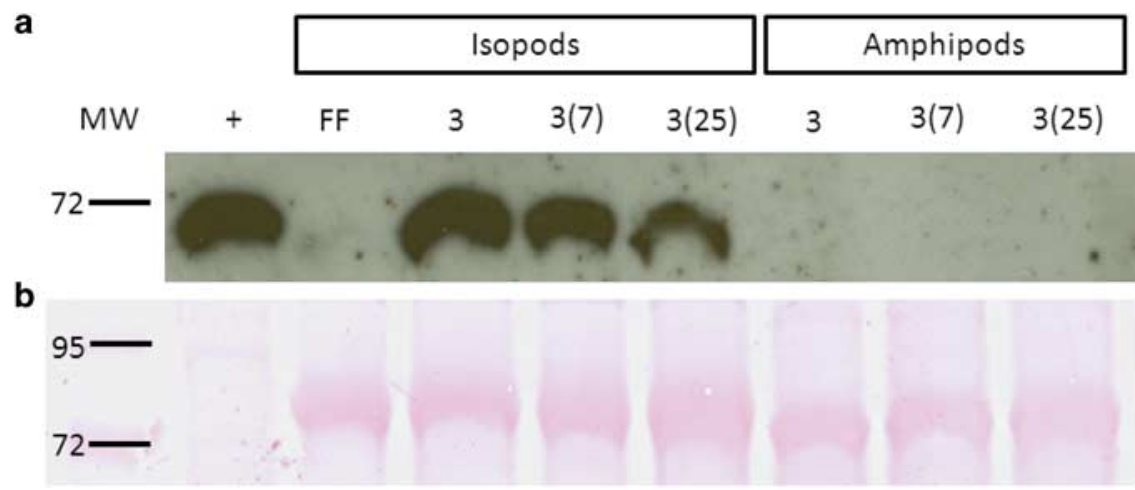

Fig. 3. Representative Western blot of proteins from isopod Exosphaeroma gigas and amphipod Hyale hirtipalma samples run on a single gel. a. The western blot shows an Hsp70 band from isopods, but no binding to any amphipod proteins. Monoclonal anti-heat shock protein 70 antibody produced in mouse (clone BRM-22, 1: 2500, Sigma \# H5147) was used as primary antibody. Molecular weight (MW, in $\mathrm{kDa}$ ) is shown on the left of the figure. HeLa was used as a positive control (indicated by + sign), and b. the Ponceau stained membrane as a loading control. $\mathrm{FF}=$ field fresh, $3=3^{\circ} \mathrm{C}$ acclimation, $3(7)=3^{\circ} \mathrm{C}$ acclimation, treated at $7^{\circ} \mathrm{C}$, $3(25)=3^{\circ} \mathrm{C}$ acclimation, treated at $25^{\circ} \mathrm{C}$. 


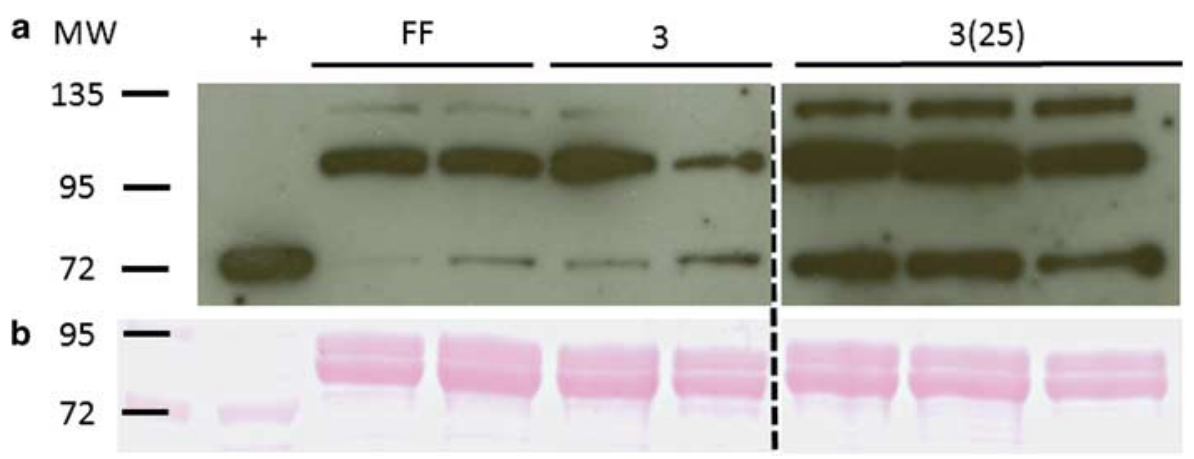

Fig. 4. a. Representative Western blot proteins from isopod Exosphaeroma gigas samples run simultaneously on two gels, and blotted onto one membrane. Molecular weight $(\mathrm{kDa})$ is given on the left of the figure. The figure shows two field fresh samples (FF), two acclimated at $3^{\circ} \mathrm{C}(3)$, and three acclimated at $3^{\circ} \mathrm{C}$ and then exposed to $25^{\circ} \mathrm{C}(3(25))$. Nonspecific binding of heat shock protein 70 (Hsp70) antibodies were detected in all samples at c. $120 \mathrm{kDa}$ and $100 \mathrm{kDa}$. Significantly more Hsp70 was detected in $3(25)$ as opposed to 3 (see Results). Monoclonal anti-heat shock protein 70 antibody produced in mouse (clone BRM-22, 1: 2500, Sigma \# H5147) was used as primary antibody. HeLa was used as a positive $(+)$ control, and b. the Ponceau stained membrane as a loading control.

$\mathrm{R}$ version 2.14.2 ( $\mathrm{R}$ Development Core Team 2012) assuming a binomial distribution and logit link function. Interactions that were not significant were removed during model simplification. A one-way ANOVA and a GLZ (binomial distribution and logit link) were used to determine whether $\log _{10}$ mass or the proportion of males to females varied between acclimation treatments. Data on relative levels of Hsp70 were $\log _{10}$ transformed to achieve

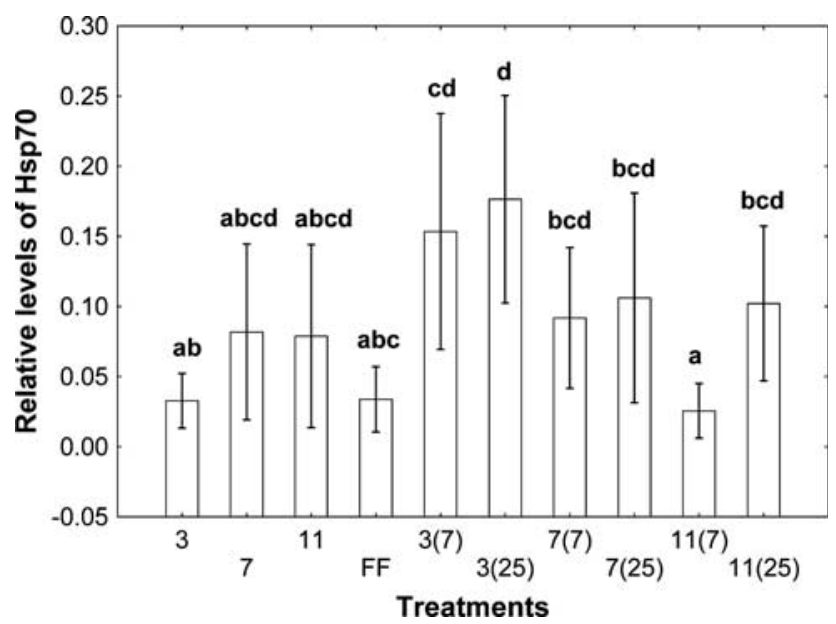

Fig. 5. Relative levels of heat shock protein 70 (Hsp70) (shown as mean $\pm 95 \%$ confidence interval; see Methods) from isopod Exosphaeroma gigas obtained for each treatment. Acclimation treatments include 3,7 and $11^{\circ} \mathrm{C}$ and two hour exposures to 7 or $25^{\circ} \mathrm{C}$ prior to Hsp assessment are indicated in parentheses. Lower case letters indicate significant differences $(P<0.05$; Tukey HSD post hoc test) between treatment groups for nested analysis of variance using $\log _{10}$ transformed Hsp70. Relative Hsp70 levels are shown on a normal scale to facilitate interpretation of the data. normality of data distribution (Shapiro-Wilks test) and equal variances (Levene's test). To identify the effects of acclimation treatments on the relative levels of Hsp70, a nested ANOVA was used with treatments and samples as covariates and replicates nested within samples. A post-hoc Tukey HSD indicated differences between treatment groups.

\section{Results}

For both species, there were no significant differences in body mass (ANOVA, H. hirtipalma: $\mathrm{df}=2, F=0.72$, $P=0.49 ;$ E. gigas: $\mathrm{df}=2, F=0.14, P=0.87)$ or the proportion of males to females (GLZ, H. hirtipalma: $\mathrm{df}=2$, $\chi^{2}=1.81, P=0.40 ;$ E. gigas: $\left.\mathrm{df}=2, \chi^{2}=0.27, P=0.87\right)$ between acclimation treatments. Results of the postacclimation ULT trials provided contrasting results between the amphipod and isopod species. For both species, and for all acclimations, temperature had a significant effect on survival (typical sigmoid shape curve; Table I, Fig. 2). The $\mathrm{ULT}_{50}$ of individuals acclimated at average habitat temperature $\left(7^{\circ} \mathrm{C}\right)$ did not differ between species (mean $(95 \%$ confidence interval range) was $26.4^{\circ} \mathrm{C}\left(26.0-27.6^{\circ} \mathrm{C}\right)$ for $H$. hirtipalma and $26.4^{\circ} \mathrm{C}\left(26.1-26.9^{\circ} \mathrm{C}\right)$ for $E$. gigas $)$. However, acclimation treatments had an effect on the ULT of E. gigas but not that of H. hirtipalma (Table I, Fig. 2). For E. gigas, the mean $\mathrm{ULT}_{50}(95 \%$ confidence interval range) at acclimations of 3,7 and $11^{\circ} \mathrm{C}$ were $25.0^{\circ} \mathrm{C}\left(22.0-25.5^{\circ} \mathrm{C}\right), 26.4^{\circ} \mathrm{C}$ $\left(26.0-27.6^{\circ} \mathrm{C}\right)$ and $29.5^{\circ} \mathrm{C}\left(29.1-29.8^{\circ} \mathrm{C}\right)$, respectively.

Hsp70 was not detected in H. hirtipalma with the three different primary antibodies used (Fig. 3). For all trials, a positive control was obtained and verified that the Western blotting process was not responsible for the lack of bands. For E. gigas, the amount of $\mathrm{Hsp} 70$ induced at $3{ }^{\circ} \mathrm{C}$ acclimation and then acutely exposed to 7 and $25^{\circ} \mathrm{C}$ for 
2 hours was significantly higher than the relative amount of Hsp70 at $3^{\circ} \mathrm{C}$ acclimation (treatment effect, $F_{1,9}=5.18$, $P<0.0001$; Tukey HSD post hoc test, Figs $4 \& 5$ ). An acute high temperature exposure following a cold acclimation induced a higher Hsp70 response than a warm acclimation alone (i.e. 3(7) and 3(25) vs 11(7), Fig. 5). By contrast, a warm acclimation at $11^{\circ} \mathrm{C}$ followed by 2 hours exposure to a lower temperature $\left(7^{\circ} \mathrm{C}\right)$ resulted in less $\mathrm{Hsp} 70$ than the same acclimation exposed to $25^{\circ} \mathrm{C}$ for 2 hours (Fig. 5). The relative amounts of Hsp70 induced during five days acclimation at 3,7 and $11^{\circ} \mathrm{C}$ were, however, not significantly different (Tukey HSD post hoc test, $P>0.05$; Fig. 5).

\section{Discussion}

The amphipod and isopod species had the same basal thermal resistance, but distinct variation in plasticity of upper lethal temperatures. Thermal acclimation influenced the survival of the isopod E. gigas with individuals tolerating warmer temperatures when exposed to higher acclimation treatments. In contrast, previous exposure to acclimation temperatures for 5-12 days made no difference to the survival of the amphipod $H$. hirtipalma. Given the temperatures and time frame used in these experiments, the lack of acclimation probably reflects a genuine inability to shift the survival curve. A five to ten day long exposure is generally sufficient to induce the majority of the acclimation effects in marine crustaceans (Claussen 1980, Morrit \& Ingólfsson 2000; but see Peck et al. 2010 for lack of acclimation in subtidal ectotherms in the Antarctic). The isopod species, which inhabits mostly submerged sites under boulders and probably encounters a more stable and predictable environment than the amphipod species (Fig. 1), showed a plastic response. However, these distinct responses could also reflect differences in evolutionary history and/or phylogenetic association between the species. For the only other species of intertidal invertebrates examined on Marion Island, mites in the genus Halozetes, acclimation response also varied in a similar manner, but was dependent on the trait being considered (Deere \& Chown 2006, Deere et al. 2006). Such similarities suggest a role for environmental predictability which is higher in the marine relative to the intertidal environment at the island (Deere \& Chown 2006).

It is surprisingly difficult to compare the magnitude of change of $\mathrm{ULT}_{50}$ from E. gigas (an increase of $4.5^{\circ} \mathrm{C}$ for $8^{\circ} \mathrm{C}$ difference in acclimation temperatures) with other species reported in the literature as most studies that examine the plasticity of heat resistance in marine crustaceans have used different methods (e.g. dynamic methods, such as critical thermal limits, Gaston \& Spicer 1998, Morritt \& Ingólfsson 2000) or protocols of lethal limits (survival time rather than proportion of individuals; e.g. Claussen 1980). Nonetheless, the few studies available
(Claussen 1980, Stillman \& Somero 2000) indicate significant plastic effects of lethal limits, generally in the direction that provides an advantage in the new environment given the prior thermal exposure. Moreover, little has been done for species in the sub-Antarctic while studies in the Arctic or Antarctic indicate that polar marine species have limited or no plasticity of critical thermal limits (Kivivuori \& Lagerspetz 1990, Peck et al. 2010). Therefore, this study shows that, in addition to having a temperature tolerance well above temperatures encountered in their habitats $\left(26.4^{\circ} \mathrm{C}\right.$ vs a maximum microsite temperature of $14.2^{\circ} \mathrm{C}$ and $9.1^{\circ} \mathrm{C}$ for the exposed and submerged site, respectively), some species in the sub-Antarctic also have the ability to acclimate to changes in temperature.

This study provides evidence that the production of Hsp70 probably plays a role in the thermal tolerance of E. gigas on Marion Island. Heat shock protein 70 levels were similar in all acclimations and in most combinations of high acclimation treatments and short-term acute temperature exposures. The maintenance of constitutive levels of Hsp70 may suggest a preparative response to potential heat exposures as found by Dong et al. (2008) for high-intertidal limpets. Acute high temperature exposure after cold acclimation resulted in a significantly higher relative amount of Hsp70, probably resulting from an increase in inducible Hsp70. Acclimation effects on Hsp responses have been shown for several other marine organisms. For example, the temperature at which a heat shock response is induced can vary with thermal history (both acclimatization and acclimation) in intertidal invertebrates (Roberts et al. 1997, Tomanek \& Somero 1999, Buckley et al. 2001, Osovitz \& Hofmann 2005). However, Clark et al. (2008b) found an absence of heat shock response in two Antarctic marine invertebrates, including a gamarid amphipod, during an acute heat-shock experiment, despite the presence of Hsp70 genes in both species. However, many studies of heat-shock response solely examine mRNA responses (e.g. Osovitz \& Hofmann 2005), and only a few include protein quantification and mRNA responses (see Bedulina et al. 2013 for freshwater amphipods). It is thus difficult to ascertain if the mRNA responses would directly result in functional protein production, as the proteins probably have a different time-course of response (see e.g. Sørensen et al. 2013). A recent investigation of two freshwater amphipod species found that increased thermotolerance could be attributed to structural and functional rearrangement of hsp 70 genes and correlated with $\mathrm{Hsp} 70$ proteins and their transcripts (Bedulina et al. 2013). Furthermore, it is not possible to ascertain if the lack of Hsp70 in the amphipod species in our current study originated from: i) a lack of the correct antibody needed to bind to and detect Hsp70 in this species, ii) temperature treatments not inducing Hsp70 production although one might have expected at least some constitutive Hsp70 detected, or iii) alterations during gene expression 
of hsp70, transcription or translation that do not lead to increased Hsp70. Lastly, the amphipod H. hirtipalma may rely on other proteins to survive temperature challenges.

Marion Island's climate has changed rapidly in the last 50 years with notable increases in maximum air (Le Roux \& McGeoch 2008) and sea surface (Mélice et al. 2003, Rouault et al. 2005) temperature. Despite the relatively large warming tolerance (Deutsch et al. 2008) of the two intertidal species $\left(12.2^{\circ} \mathrm{C}\right.$ and $17.3^{\circ} \mathrm{C}$, respectively; calculated here as mean $\mathrm{ULT}_{50}$ minus maximum microsite temperature), the lack of plasticity and probable absence of Hsp70 response in the amphipod makes this species more vulnerable to climatic changes than the isopod. There is evidence that marine crustaceans in the sub-Antarctic can move across relatively large ocean distances by rafting on macroalgae that drift with winds and ocean currents, in particular with the Antarctic Circumpolar Current (Nikula et al. 2010, Fraser et al. 2011). Therefore, studies that couple phylogeographic patterns of $H$. hirtipalma and E. gigas in the sub-Antarctic region with the investigation of heat shock responses (including both gene sequencing and protein quantification) would enhance understanding of these species' capacities to buffer climate change. In particular, it may clarify if $H$. hirtipalma has lost the regulatory gene mechanisms for Hsp70 and/or the expression of these proteins compared to close relatives, or if these mechanisms are absent from this taxonomic group altogether.

\section{Acknowledgements}

The authors thank Sharon Kang for assistance with protein extractions and Jomien Mouton and Dr Craig Kinnear of the Magic Lab, Division of Molecular Biology and Human Genetics, Department Biomedical Sciences, University of Stellenbosch for advice and the kind use of their facilities for Western blotting. John S. Terblanche and two anonymous referees provided useful comments on the manuscript. This research was supported by an Antarctic Science bursary to SCT, British Antarctic Survey Grant 41326, the South African National Antarctic Programme and Harry Crossley bursary to LB.

\section{References}

Angilletta JR, M.J. 2009. Thermal adaptation: a theoretical and empirical synthesis. New York: Oxford University Press, 320 pp.

Barua, D. \& HeCKathorn, S.A. 2004. Acclimation of the temperature set-points of the heat shock response. Journal of Thermal Biology, 29, 185-193.

Bedulina, D.S., Evgen'ev, M.B., Timofeyev, M.A., Protopopova, M.V., Garbuz, D.G., Pavlichenko, V.V., Luckenbach, T., Shatilina, Z.M., Axenov-Gribanov, D.V., Gurkov, A.N., SoKolova, I.M. \& Zatsepina, O.G. 2013. Expression patterns and organization of the hsp 70 genes correlate with thermotolerance in two congener endemic amphipod species (Eulimnogammarus cyaneus and E. verrucosus) from Lake Baikal. Molecular Ecology, 22, 1416-1430.
Branch, M.L., Griffiths, C.L., Kensley, B. \& Sieg, J. 1991. The benthic Crustacea of sub-Antarctic Marion and Prince Edward Islands: illustrated keys to the species and results of the 1982-1989 University of Cape Town surveys. South African Journal of Antarctic Research, 21, $3-44$.

Buckley, B.A., Owen, M.-E. \& Hofmann, G.E. 2001. Adjusting the thermostat: the threshold induction temperature for the heat-shock response in intertidal mussels (genus Mytilus) changes as a function of thermal history. The Journal of Experimental Biology, 204, 3571-3579.

Chapple, J.P., Smerdon, G.R., Berry, R.J. \& Hawkins, A.J.S. 1998. Seasonal changes in stress-70 protein levels reflect thermal tolerance in the marine bivalve Mytilus edulis L. Journal of Experimental Marine Biology and Ecology, 229, 53-68.

Clark, M.S., Fraser, K.P.P. \& Peck, L.S. 2008a. Antarctic marine molluscs do have an Hsp70 heat shock response. Cell Stress and Chaperones, 13, 39-49.

Clark, M.S., Fraser, K.P.P. \& PeCK, L.S. 2008b. Lack of an HSP70 heat shock response in two Antarctic marine invertebrates. Polar Biology, 31, 1059-1065.

Claussen, D.L. 1980. Thermal acclimation in the crayfish, Orconectes rusticus and $O$. virilis. Comparative Biochemistry and Physiology, 66A, 377-384.

Davenport, J. \& Davenport, J.L. 2005. Effects of shore height, wave exposure and geographical distance on thermal niche width of intertidal fauna. Marine Ecology Progress Series, 292, 41-50.

Davenport, J. \& MacAlister, H. 1996. Environmental conditions and physiological tolerances of intertidal fauna in relation to shore zonation at Husvik, South Georgia. Journal of Marine Biological Association of the United Kingdom, 76, 985-1002.

De Villiers, A.F. 1976. Littoral ecology of Marion and Prince Edward Islands (Southern Ocean). South African Journal of Antarctic Research, 1, 1-40.

Deere, J.A. \& Chown, S.L. 2006. Testing the beneficial acclimation hypothesis and its alternatives for locomotor performance. American Naturalist, 168, 630-644.

Deere, J.A., Sinclair, B.J., Marshall, D.J. \& Chown, S.L. 2006. Phenotypic plasticity of thermal tolerances in five oribatid mite species from sub-Antarctic Marion Island. Journal of Insect Physiology, 52, 693-700.

Deutsch, C.A., Tewksbury, J.J., Huey, R.B., Sheldon, K.S., Ghalambor, C.K., HAAK, D.C. \& MARTIN, P.R. 2008. Impacts of climate warming on terrestrial ectotherms across latitude. Proceedings of the National Academy of Sciences of the United States of America, 105, 6668-6672.

Dong, Y., Miller, L.P., SAnders, J.G. \& Somero, G.N. 2008. Heat-shock protein 70 (Hsp70) expression in four limpets of the Genus Lottia: interspecific variation in constitutive and inducible synthesis correlates with in situ exposure to heat stress. The Biological Bulletin, 215, 173-181.

Ferreira, T. \& Rasband, W. 2011. The ImageJ user guide. http:// imagej.nih.gov/ij/docs/guide/, accessed October 2011.

Fraser, C.I., Nikula, R. \& Waters, J.M. 2011. Oceanic rafting by a coastal community. Proceedings of the Royal Society, B278, 649-655.

Gabriel, W. \& LyNCH, M. 1992. The selective advantage of reaction norms for environmental tolerance. Journal of Evolutionary Biology, 5, 41-59.

Gaston, K.J. \& Spicer, J.I. 1998. Do upper thermal tolerances differ in geographically separated populations of the beachflea Orchestia gammarellus (Crustacea: Amphipoda)? Journal of Experimental Marine Biology and Ecology, 229, 265-276.

Karl, I., Sørensen, J.G., Loeschcke, V. \& Fischer, K. 2009. HSP70 expression in the Copper butterfly Lycaena tityrus across altitudes and temperatures. Journal of Evolutionary Biology, 22, 172-178.

Kelly, M.W., SAnford, E. \& Grosberg, R.K. 2011. Limited potential for adaptation to climate change in a broadly distributed marine crustacean. Proceedings of the Royal Society, B279, 349-356.

Kivivuori, L. \& LagerspetZ, K.Y.H. 1990. Thermal resistance and behaviour of the isopod Saduria entomon (L.). Annales Zoologici Fennici, 27, 287-290. 
La Terza, A., Papa, G., Miceli, C. \& Luporini, P. 2001. Divergence between two Antarctic species of the ciliate Euplotes, E. focardii and E. nobilii, in the expression of heat-shock protein 70 genes. Molecular Ecology, 10, 1061-1067.

Le Roux, P.C. \& McGeoch, M.A. 2008. Changes in climate extremes, variability and signature on sub-Antarctic Marion Island. Climatic Change, 86, 309-329.

Mélice, J-L., Lutjeharms, J.R.E., Rounault, M. \& Ansorge, I.J. 2003. Sea-surface temperatures at the sub-Antarctic islands Marion and Gough during the past 50 years. South African Journal of Science, 99, 363-366.

Morritt, D. \& Ingólfsson, A. 2000. Upper thermal tolerance of the beachflea Orchestia gammarellus (Pallas) (Crustacea: Amphipoda: Talitridae) associated with hot springs in Iceland. Journal of Experimental Marine Biology and Ecology, 255, 215-227.

Nikula, R., Fraser, C.I., Spencer, H.G. \& Walters, J.M. 2010. Circumpolar dispersal by rafting in two sub-Antarctic kelp-dwelling crustaceans. Marine Ecology Progress Series, 405, 221-230.

Osovitz, C.J. \& HofmanN, G.E. 2005. Thermal history-dependent expression of the hsp gene in purple sea urchins: biogeographic patterns and the effect of temperature acclimation. Journal of Experimental Marine Biology and Ecology, 327, 134-143.

Peck, L.S., Convey, P. \& Barnes, K.A. 2006. Environmental constraints on life histories in Antarctic ecosystems: tempos, timings and predictability. Biological Reviews, 81, 75-109.

Peck, L.S., Morley, S.A. \& Clark, M.S. 2010. Poor acclimation capacities in Antarctic marine ectotherms. Marine Biology, 157, 2051-2059.

Roberts, D.A., Hofmann, G.E. \& Somero, G.N. 1997. Heat-shock protein expression in Mytilus californianus: acclimatization (seasonal and tidal-height comparisons) and acclimation effects. The Biological Bulletin, 192, 309-320.

Romero-Calvo, I., Ocón, B., Martínez-Moya, P., Suárez, M.D., Zarzuelo, A., Martínez-Augustin, O. \& De Medina, F.S. 2010. Reversible Ponceau staining as a loading control alternative to actin in Western blots. Analytical Biochemistry, 401, 318-320.
Rouault, M., Mélice, J-L., Reason, C.J.C. \& Lutjeharms, J.R.E. 2005. Climate variability at Marion Island, Southern Ocean, since 1960. Journal of Geophysical Research, 10.1029/2004JC002492.

Sinclair, E.L.E., Thompson, M.B. \& Seebacher, F. 2006. Phenotypic flexibility in the metabolic response of the limpet Cellana tramoserica to thermally different microhabitats. Journal of Experimental Marine Biology and Ecology, 335, 131-141.

Sørensen, J.G., Loeschcke, V. \& Kristensen, T.N. 2013. Cellular damage as induced by high temperature is dependent on the rate of temperature change - investigating consequences of ramping rates on molecular and organismal phenotypes in Drosophila melanogaster Meigen 1830. Journal of Experimental Biology, 216, 809-814.

Stillman, J.H. 2003. Acclimation capacity underlies susceptibility to climate change. Science, 301, 65.

Stillman, J.H. \& Somero, G.N. 2000. A comparative analysis of the upper thermal tolerance limits of Eastern Pacific porcelain crabs, Genus Petrolisthes: influences of latitude, vertical zonation, acclimation and phylogeny. Physiological and Biochemical Zoology, 73, 200-208.

TOMANEK, L. 2010. Variation in heat shock response and its implication for predicting the effect of global climate change on species' biogeographical distribution ranges and metabolic costs. Journal of Experimental Biology, 213, 971-979.

TOMANEK, L. \& SOMERo, G.N. 1999. Evolutionary and acclimation-induced variation in the heat-shock responses of congeneric marine snails (Genus Tegula) from different thermal habitats: implications for limits of thermaotolerance and biogeography. Journal of Experimental Biology, 202, 2925-2936.

TOMANEK, L. \& SOMERo, G.N. 2002. Interspecific- and acclimationinduced variation in levels of heat-shock proteins 70 (hsp70) and 90 (hsp90) and heat-shock transcription factor-1 (HSF1) in congeneric marine snails (genus Tegula): implications for regulation of hsp gene expression. Journal of Experimental Biology, 205, $677-685$. 